\title{
National Civil Aviation Policy Implementation in Nigeria: An Empirical Study
}

\author{
POPOOLA O. Olufemi PhD OLORODE Damilola B. \\ Department of Public Administration, Obafemi Awolowo University, Ile-Ife, Nigeria
}

\begin{abstract}
The study examined the various programmes put in place by the Ministry of Aviation towards the implementation of government policy on civil aviation and assessed the extent of implementation of the national civil aviation policy in line with the set goals and objectives in Southwestern Nigeria. The study utilized primary and secondary sources of data. Primary data were collected through the administration of questionnaire and conduct of in-depth interviews. In all, 193 copies of questionnaire were administered to the staff of Nigerian Civil Aviation Authority (NCAA); Federal Airports Authority of Nigeria (FAAN); Nigerian Airspace Management Agency (NAMA) and Accident Investigation Bureau (AIB) in the three selected States (Lagos, Oyo and Ondo) of Southwestern Nigeria. In-depth interviews were conducted on eight Directors in the four aviation agencies to complement data obtained through questionnaire. Secondary data were sourced from books, official publications, academic journals, newspapers, magazines and internet materials. Data collected were analysed using simple percentages, frequency counts, mean values, and rank. The results showed that adequate personnel training (84\%) and the development of institutional infrastructures for aviation agencies $(76 \%)$ were programmes put in place by the Ministry of Aviation towards the implementation of civil aviation policy. On the extent of implementation, the study however revealed that, technical personnel were not adequately trained for professionalism and efficiency in air operations (with a mean value of 3.582) and all necessary equipment, technologies and institutional infrastructures were inadequately provided to civil aviation departments and agencies to prevent and counter new and emerging threats (with a mean value of 3.144). The study concluded that government policy on civil aviation in Southwestern had been poorly implemented to date.
\end{abstract}

Keywords: Assessment, Trade Development, Implementation, Government Policy, Civil Aviation

DOI: $10.7176 / \mathrm{JLPG} / 88-26$

Publication date: August $31^{\text {st }} 2019$

\section{Introduction}

The crucial role played by air transport in driving sustainable economic and social development worldwide cannot be overemphasized. The Global Aviation Safety Plan (GASP 2014-2016) reports that air transport worldwide provides employment for about 56.6 million people, makes over \$2 trillion contribution to global total national output (Gross Domestic Product) and conveys more than 2.5 billion travelers and $\$ 5.3$ trillion worth of payload annually. The 2010 Iceland's volcanic ash which brought about the shutdown of three hundred European air terminals for five days, cancellation of over a hundred thousand flights, more than ten million stranded passengers and \$5 billion deficit in Gross Domestic Product (GDP) worldwide spotlighted the socioeconomic impact aviation is making globally.

Aviation provides the only rapid and efficient worldwide transportation network, thus facilitating global business and tourism which are requisite for economic growth, particularly in developing countries such as Nigeria. According to a report published by Oxford Economics (2010), the aviation sector's overall contribution to Nigerian GDP was 198 billion Nigerian Naira $(0.6 \%)$. This was generated through the output of airlines, airports, ground services, aviation supply chain etc. The aviation sector also supported the employment of about 159,000 indigenes and foreigners in addition to the 130,000 people employed through the catalytic (tourism) effects of aviation. In addition, aviation is a feasible means of generating revenues through personal income tax, company tax, profit tax etc. Other areas where aviation makes significant contributions include: trade development, foreign direct investment opportunity, tourism development etc. As the demand for air transport services grow, its influence on the nation and global economy also increases thereby enhancing fast and easy movement of passengers, goods and services to the local and international markets. The Nigerian aviation sector in particular has been witnessing improved patronage in air transport services due to the series of economic activities which have been generating additional tax revenue and surge in tourism. It can therefore be stated that the aviation sector has been contributing to the economy by way of fast tracking in, and out, flow of goods and services.

Due to the growing liberalization that has permeated all aspects of the aviation industry, healthy competition has helped promote security, efficiency and quality of services. While liberalization and privatization are gradually and steadily taking over the aviation business, governments are now restricting themselves to the setting of a sustainable policy framework upon which healthy competition will thrive in the industry. 
Regardless of all its economic benefits, civil aviation is not without its own challenges. Despite the fact that civil aviation appears to be the most regulated industry in the world, accidents still happen and in order to further reduce accidents and improve safety, proactive approaches must be adopted by the aviation community. According to a report by the African Development Bank (AfDB, 2012) the performance of the African aviation industry is still lagging behind those of the rest of the world. The Global Safety Information Exchange (GSIE) rating contained in the ICAO Safety Report (2014), states that while Africa accounted for the lowest percentage of global traffic volume at only $2 \%$, it had the highest regional accident rate at $10 \%$ of the global share. Cognizant of the major challenges that Africa faces related to aviation safety, several programmes have been put in place for aviation industry in Nigeria to develop a safe and secure aviation sector that delivers significant socio-economic benefits to Nigerians. This paper therefore examined the programmes put in place by the Ministry of Aviation with a view to assessing the extent of the implementation of such programmes in Southwestern Nigeria.

\section{Literature Review}

There is a lack of consensus over the meaning of public policy. Thomas (1984) defines public policy as whatever the government chooses to do or not to do. On the other hand, Ikelegbe (1996) defined public policy as government's course of proposed actions directed at achieving specified goals. Similarly, Leslie (1997) on her own part, views public policy as a plan of action or inaction by public authorities to tackle a given societal problem(s). According to Ezeani (2006) public policy is perceived as the proposed programme of action which government sets out to execute in response to identified problems. Public policy may be conceptualized as a policy made at governmental level which therefore affects the general public within the area of jurisdiction of the government or institution formulating the policy (Ocheocha, 1998).

The point of convergence of the differing views is premised on the assumption that public policy is "what" and "how" of government activities. It is the written intention of government that is aimed at solving certain problems. Public policy is the framework set up by government to aid direction and practices in certain problem areas. Once a policy is adopted, it guides activities and practices and serves as a framework for present and future decisions. The chosen course of action could be just a statement of intention or a concrete action and it could also be the absence of action. This means that government inaction in a particular problem area could be regarded as its policy response. Public policy as a rule sets out to achieve specific objectives. It is aimed at the fulfilment of certain ends.

Policy implementation however, is generally considered as the most critical phase after policy formulation in the policy process. It is probably due to its central role in the policy process that made certain scholars allude to the policy implementation stage as the crux of the public policy process. According to Sabatier and Mazmanian (1979) policy implementation determines the success or failure of a policy. Bhuyan, Jorgensen and Sharma (2010) argued that policy implementation primarily emphasises the mechanisms, resources, and relationships that link policies to programme actions.

The literature on policy science defined policy implementation in various ways. To begin with, Meter and Horn (1975) hold that, "policy implementation encompasses those actions by public or private individuals (or groups) that are directed at the achievement of objectives set forth in prior policy decisions". This definition highlighted two important features of policy implementation: (i) collective effort of public and private individuals such as government, civil society actors and individuals (ii) achievement of the objectives which are laid down in the policy content. In a similar vein, Nakamura and Smallwood (1980) understood policy implementation as a process aimed at accomplishing the goals of a policy. They further defined policy implementation as "the set of activities and operations undertaken by various stakeholders toward the achievement of goals and objectives defined in an authorised policy".

Policy implementation basically refers to the procedure of transforming a statement of intention into action or reality typically through executed programmes and projects. Kraft and Furlong (2007) and Ajaegbu and Eze (2010) implied that policy implementation is the action part/stage of the policy process. Policy implementation involves a number of activities such as: allocation of funds, awarding of contracts, data gathering, assigning tasks, enforcing regulations, delegating responsibilities, hiring employees etc. (Nweke, 2006). The effective implementation or otherwise of public policy explains the success or failure of any given policy. Corroborating this assertion, Nwankwo and Apeh (2008) opined that policy implementation is a critical stage in the policy process as the success or failure of a policy is largely determined by the effectiveness of implementation. In their views, Ikelegbe (2006) and Nweke (2006) argued that most policy failures are a function of ineffective and inefficient implementation. Simply put, the success story of any policy is effective implementation. Without effective implementation, there is no policy so to say. Dick (2003) similarly pointed out the importance of policy implementation in the policy process. He argued that the success or failure of a policy is to a large extent a function of implementation. However, a number of factors may constitute hindrance to the effective implementation of public policy. Ikelegbe (2006) thus did justice by identifying some of the critical questions 
that border on the implementation of most policies as given below:

$>$ How is the designated institution implementing the policy?

$>$ How is the implementation being perceived by the target group?

$>$ Are the resources at the disposal of the implementing institution adequate to implement the policy effectively?

$>$ Is the implementing institution willing and motivated to implement the policy as expected?

$>$ Is the perceived social problem well understood through popular consultation with stakeholders and the policy being implemented addressing the problem in the right direction?

$>$ To what extent does personal interest or bias hinder or interfere in the implementation of policy by the designated institutions?

$>$ How is the process of implementation being monitored and supervised by the appropriate government body?

\section{Theoretical Framework}

This paper derives its theoretical foundation from the Institutional Theory of Public Policy in order to contextualize its line of analysis. The institutional approach to the study of public policy which was popularised by Thomas Dye (1972) is concerned with explaining how governmental institutions and structural arrangements bring influence to bear in the public policy process. The institutional approach attempts to analyse the relationship between public policy and governmental institutions.

Government institutions refer to a set of standardised behaviours/practices of individuals and groups which have impacts on public policy making, public policy content and public policy implementation. The institutional approach exemplifies that the institutions of government may be strategically structured in such a manner that would ease the attainment of predetermined goals. Certain interests may be given priority and consideration over the others under institutionalism. Rules, regulations and procedures are mostly not neutral in effect. They are put in place to favour certain interests, individuals or groups over the others. Under institutional approach, policy making, policy content and policy implementation are to a large extent a function of institutional arrangement.

\section{Methodology}

The total study population was 3,858 respondents drawn from the Nigerian Civil Aviation Authority (939), Federal Airports Authority of Nigeria (1,792), Nigerian Airspace Management Agency $(1,055)$ and Accident Investigation Bureau (72) in Lagos, Oyo and Ondo States. The method used in selecting respondents for this study was purposive sampling techniques. The choice of the purposive sampling technique in this research was predicated upon the fact that the primary data required for this study could only be provided by staff (whose status ranges from level 12 to 17) of the aviation agencies that are considered the implementers of civil aviation policy and are well informed and possess adequate knowledge of the subject matter of this study. This necessitated a conscious selection of the individuals with such unique characteristics. The sample size covered all the four aviation agencies (NCAA, FAAN, NAMA and AIB) that are headquartered and domiciled in Southwestern Nigeria (Lagos State).

1. One hundred and ninety-three (193) copies of questionnaire were administered to the respondents at the selected aviation agencies in the following order: NCAA, Lagos - 47 copies; FAAN, Lagos - 82 copies; FAAN, Ibadan - 4 copies; FAAN, Akure - 3 copies; NAMA, Lagos - 49 copies; NAMA, Ibadan -2 copies; NAMA, Akure - 2 copies; and AIB, Lagos - 4 copies

2. Interviews were conducted on eight (8) Directors in the selected aviation agencies. They were: Consumer Protection at NCAA; Operations and Training at NCAA; MD of FAAN; Airport Operation at FAAN; GM Security and Dangerous Foods at AIB; Head, Human Resources and Administration at AIB; Engineering Services at NAMA; and GM procurement at NAMA. Secondary data for this study which focused on civil aviation were sourced from books, academic journals, thesis publications, newspapers, magazines and internet materials. The primary data were analyzed using simple percentages, frequency counts, mean and rank with the aid of the Statistical Package for Social Sciences software (SPSS version 13.0). The qualitative data obtained from the interview were analyzed using content analysis.

\section{Results}

Objective 1: The Various Programmes put in Place by the Ministry of Aviation Towards the Implementation of Government Policy on Civil Aviation in Southwestern Nigeria. 
Table 1: Distribution of the Programmes Put in Place by the Ministry of Aviation Towards Implementation of Government Policy on Civil Aviation.

\begin{tabular}{|c|c|c|c|c|c|c|}
\hline ITEMS & SA & $\mathbf{A}$ & $\mathbf{U}$ & D & SD & Total \\
\hline & $f(\%)$ & $f(\%)$ & $f(\%)$ & $f(\%)$ & $f(\%)$ & $f(\%)$ \\
\hline $\begin{array}{l}\text { For the development and growth of civil aviation in } \\
\text { Nigeria, aviation training institutions should be provided } \\
\text { with all institutional infrastructural facilities and state of } \\
\text { the art technologies. }\end{array}$ & $\begin{array}{l}124 \\
(84.9)\end{array}$ & $\begin{array}{l}20 \\
(13.7)\end{array}$ & $\begin{array}{l}1 \\
(0.7)\end{array}$ & & $\begin{array}{l}1 \\
(0.7)\end{array}$ & $\begin{array}{l}146 \\
(100)\end{array}$ \\
\hline $\begin{array}{l}\text { NCAA should be autonomous and empowered to carry out } \\
\text { effective safety oversight and regulations of the aviation } \\
\text { industry to ensure that the safety regulatory regime of } \\
\text { Nigeria meets ICAO SARPs. }\end{array}$ & $\begin{array}{l}111 \\
(76.0)\end{array}$ & $\begin{array}{l}34 \\
(23.3)\end{array}$ & - & - & $\begin{array}{l}1 \\
(0.7)\end{array}$ & $\begin{array}{l}146 \\
(100)\end{array}$ \\
\hline $\begin{array}{l}\text { The establishment of an automous unit known as } \\
\text { Economic Regulatory Unit under the office of the } \\
\text { Honourable Minister will help check potential misuse of } \\
\text { market power by aviation service providers by fostering } \\
\text { fair commercial environment where passengers receive } \\
\text { quality services at reasonable prices. }\end{array}$ & $\begin{array}{l}28 \\
(19.2)\end{array}$ & $\begin{array}{l}48 \\
(32.9)\end{array}$ & $\begin{array}{l}31 \\
(21.2)\end{array}$ & $\begin{array}{l}23 \\
(15.7)\end{array}$ & $\begin{array}{l}16 \\
(11.0)\end{array}$ & $\begin{array}{l}146 \\
(100)\end{array}$ \\
\hline $\begin{array}{l}\text { Nigeria should continue to have an autonomous accident } \\
\text { investigation and prevention agency - AIB for the } \\
\text { investigation of aircraft accidents and major incidents and } \\
\text { for the responsibility of family assistance to victims of air } \\
\text { accidents and incidents. }\end{array}$ & $\begin{array}{l}97 \\
(66.4)\end{array}$ & $\begin{array}{l}47 \\
(32.2)\end{array}$ & $\begin{array}{l}2 \\
(1.4)\end{array}$ & - & - & $\begin{array}{l}146 \\
(100)\end{array}$ \\
\hline $\begin{array}{l}\text { Commercialisation and Privatisation of airports and air } \\
\text { navigation services will help develop world class aviation } \\
\text { sector that meets ICAO SARPs }\end{array}$ & $\begin{array}{l}34 \\
(23.3)\end{array}$ & $\begin{array}{l}29 \\
(19.9)\end{array}$ & $\begin{array}{l}29 \\
(19.9)\end{array}$ & $\begin{array}{l}30 \\
(20.5)\end{array}$ & $\begin{array}{l}24 \\
(16.4)\end{array}$ & $\begin{array}{l}146 \\
(100)\end{array}$ \\
\hline $\begin{array}{l}\text { For reasons of safety and security, non-scheduled flight } \\
\text { operations within the territorial waters of Nigeria should } \\
\text { be monitored and controlled }\end{array}$ & $\begin{array}{l}88 \\
(60.3)\end{array}$ & $\begin{array}{l}51 \\
(34.9)\end{array}$ & $\begin{array}{l}3 \\
(2.1)\end{array}$ & $\begin{array}{l}3 \\
(2.1)\end{array}$ & $\begin{array}{l}1 \\
(0.6)\end{array}$ & $\begin{array}{l}146 \\
(100)\end{array}$ \\
\hline $\begin{array}{l}\text { Liberalisation of air cargo services will encourage air } \\
\text { cargo operations that are needed for competitive trade and } \\
\text { investment. }\end{array}$ & $\begin{array}{l}58 \\
(39.7)\end{array}$ & $\begin{array}{l}74 \\
(50.7)\end{array}$ & $\begin{array}{l}10 \\
(6.9)\end{array}$ & - & $\begin{array}{l}4 \\
(2.7)\end{array}$ & $\begin{array}{l}146 \\
(100)\end{array}$ \\
\hline $\begin{array}{l}\text { Development of aerotropolis around major airports is } \\
\text { expected to facilitate rapid commercial development which } \\
\text { will transform key airports into airport cities, thus driving } \\
\text { economic development. }\end{array}$ & $\begin{array}{l}68 \\
(46.6)\end{array}$ & $\begin{array}{l}66 \\
(45.2)\end{array}$ & $\begin{array}{l}8 \\
(5.4)\end{array}$ & $\begin{array}{l}2 \\
(1.4)\end{array}$ & $\begin{array}{l}2 \\
(1.4)\end{array}$ & $\begin{array}{l}146 \\
(100)\end{array}$ \\
\hline $\begin{array}{l}\text { Every strategic decision, policy, and procedure that has } \\
\text { been developed to move the aviation sector to an } \\
\text { internationally acceptable operational level should be } \\
\text { reviewed annually to reflect the dynamics of the Nigerian } \\
\text { Aviation Sector. }\end{array}$ & $\begin{array}{l}69 \\
(47.3)\end{array}$ & $\begin{array}{l}63 \\
(43.1)\end{array}$ & $\begin{array}{l}8 \\
(5.5)\end{array}$ & $\begin{array}{l}5 \\
(3.4)\end{array}$ & $\begin{array}{l}1 \\
(0.7)\end{array}$ & $\begin{array}{l}146 \\
(100)\end{array}$ \\
\hline
\end{tabular}

Source: Field Survey, 2018

Note: $\mathrm{F}=$ Frequency, $\%=$ Percentage, $\mathrm{SA}=$ Strongly agree, $\mathrm{A}=$ Agree, $\mathrm{U}=$ Undecided, $\mathrm{D}=\mathrm{Disagree}$ and $\mathrm{SD}=$ Strongly disagree

The distribution as summarised in Table 1 examined respondents' views on various programmes put in place by the ministry of aviation towards the implementation of civil aviation policy. Nine of the programmes of the ministry of aviation were identified and examined. Majority of the respondents $(84 \%)$ strongly agreed that adequate personnel training is one programme required for development and growth of civil aviation in Nigeria. Similarly, (76.0\%) of the respondents strongly agreed that "NCAA should be autonomous and empowered to carry out effective safety oversight and regulations of the aviation industry to ensure that the safety regulatory regime of Nigeria meets ICAO SARPs". 32.9\% of the respondents agreed that "The establishment of an automous unit known as Economic Regulatory Unit under the office of the Honourable Minister will help check potential misuse of market power by aviation service providers by fostering fair commercial environment where passengers receive quality services at reasonable prices". It thus interpretes that regulating the activities of aviation service providers will help check misuse of market power while ensuring that passengers get value for their money. In addition, $66.4 \%$ of the respondents strongly agreed that "Nigeria should continue to have an autonomous accident investigation and prevention agency - AIB for the investigation of aircraft accidents and major incidents and for the responsibility of family assistance to victims of air accidents and incidents". 
The results further showed that $23.3 \%$ of the respondents strongly agreed and $19.9 \%$ agreed while $20.5 \%$ disagreed and $16.4 \%$ strongly disagreed that "Commercialisation and Privatization of airports and air navigation services will help develop world class aviation sector that meets ICAO SARPs". This result shows that more respondents still tended towards agreement with this assertion. Also, 60.3\% of the respondents strongly agreed that "For reasons of safety and security, non-scheduled flight operations within the territorial waters of Nigeria should be monitored and controlled". About half, 50.7\% of the respondents agreed that "Liberalisation of air cargo services will encourage air cargo operations that are needed for competitive trade and investment". This implies that removal of restrictions will create enabling environment for air cargo operations which in turn will facilitate growth of trade and investment. Similarly, $46.6 \%$ and $45.2 \%$ of the respondents strongly agreed and ordinarily agreed that "Development of aerotropolis around major airports is expected to facilitate rapid commercial development which will transform key airports into airport cities, thus driving economic development" respectively. The findings of this statement depicts that the aerotropolis concept will not only bring commercial activities around the airports but will also drive rapid economic development. Further, $47.3 \%$ and $43.1 \%$ of the respondents strongly agreed and agreed with the statement that "every strategic decision, policy, and procedure that has been developed to move the aviation sector to an internationally acceptable operational level should be reviewed annually to reflect the dynamics of the Nigerian Aviation Sector respectively.

The summary of the descriptive statistics on the various programmes put in place by the ministry of aviation towards the implementation of government policy on civil aviation is further presented in Table 2 below.

Table 2: Descriptive Statistics of the Various Programmes Put in Place by the Ministry of Aviation Towards the Implementation of Government Policy on Civil Aviation

\begin{tabular}{|c|c|c|c|c|}
\hline ITEMS & Weight & Mean & SD & Rank \\
\hline $\begin{array}{l}\text { For the development and growth of civil aviation in Nigeria, aviation } \\
\text { training institutions should be provided with all institutional infrastructural } \\
\text { facilities and state of the art technologies. }\end{array}$ & 704 & 4.872 & 0.371 & 1 \\
\hline $\begin{array}{l}\text { NCAA should be autonomous and empowered to carry out effective safety } \\
\text { oversight and regulations of the aviation industry to ensure that the safety } \\
\text { regulatory regime of Nigeria meets ICAO SARPs. }\end{array}$ & 692 & 4.798 & 0.424 & 2 \\
\hline $\begin{array}{l}\text { The establishment of an automous unit known as Economic Regulatory Unit } \\
\text { under the office of the Honourable Minister will help check potential misuse } \\
\text { of market power by aviation service providers by fostering fair commercial } \\
\text { environment where passengers receive quality services at reasonable prices. }\end{array}$ & 487 & 3.809 & 1.060 & 8 \\
\hline $\begin{array}{l}\text { Nigeria should continue to have an autonomous accident investigation and } \\
\text { prevention agency - AIB for the investigation of aircraft accidents and major } \\
\text { incidents and for the responsibility of family assistance to victims of air } \\
\text { accidents and incidents. }\end{array}$ & 679 & 4.705 & 0.476 & 3 \\
\hline $\begin{array}{l}\text { Commercialisation and Privatisation of airports and air navigation services } \\
\text { will help develop world class aviation sector that meets ICAO SARPs }\end{array}$ & 457 & 3.761 & 1.230 & 9 \\
\hline $\begin{array}{l}\text { For reasons of safety and security, non-scheduled flight operations within } \\
\text { the territorial waters of Nigeria should be monitored and controlled }\end{array}$ & 660 & 4.630 & 0.579 & 4 \\
\hline $\begin{array}{l}\text { Liberalisation of air cargo services will encourage air cargo operations that } \\
\text { are needed for competitive trade and investment. }\end{array}$ & 620 & 4.400 & 0.646 & 7 \\
\hline $\begin{array}{l}\text { Development of aerotropolis around major airports is expected to facilitate } \\
\text { rapid commercial development which will transform key airports into airport } \\
\text { cities, thus driving economic development. }\end{array}$ & 634 & 4.476 & 0.635 & 5 \\
\hline $\begin{array}{l}\text { Every strategic decision, policy, and procedure that has been developed to } \\
\text { move the aviation sector to an international acceptable operational level } \\
\text { should be reviewed annually to reflect the dynamics of the Nigerian } \\
\text { Aviation Sector. }\end{array}$ & 632 & 4.472 & 0.665 & 6 \\
\hline
\end{tabular}

Source: Field Survey, 2018

As presented in the table 2 above, the results showed that respondents agreed with all the 9 statements. This suggests that respondents have positive view about various programmes put in place by the Ministry of aviation towards implementation of civil aviation policy. The highest ranked item was the statement that "For the development and growth of civil aviation in Nigeria, aviation training institutions should be provided with all institutional infrastructural facilities and state of the art technologies" with mean value of 4.872. Also, the statement that "commercialisation and Privatization of airports and air navigation services will help develop world class aviation sector that meets ICAO SARPs" was the least ranked item with the mean score of 3.761.

In addition to the programmes identified above, it was gathered from the interview that, remodelling of 
Murtala Mohammed Airport Terminal 2 (MMA2); the PPP programme under which MMA2 was given on concession to Bi-Courtney Aviation Services Limited; the plan to develop Lagos Airport to become the hub of West Africa; the plan to make some designated airports cargo terminals; the process of establishing National Carrier based on the recommendation of the aviation committee; the policy which mandates NNPC to be supplying Jet A-1 (fuel used for commercial aviation) to the aviation industry; the building of aerotropolis; the institution of Consumer Protection Directorate within NCAA to protect the interests of consumers and according to the interviewee from NAMA, the mandate to provide air navigational and air traffic services which include the procurement, installation and maintenance of air navigational facilities were some of the programmes put in place by the Ministry of Aviation towards the implementation of the civil aviation policy. Stating their different reasons however, the consensus among interviewees was that the programmes put in place by the Ministry of Aviation towards the implementation of civil aviation policy had not actually addressed the objectives of NCAP.

Objective 2: The Extent of the Implementation of the National Civil Aviation Policy in Line with the set Goals and Objectives.

Table 3: Assessment of the Extent of Implementation of the National Civil Aviation Policy in Line with the Set Goals and Objectives

\begin{tabular}{|c|c|c|c|c|c|c|}
\hline ITEMS & SA & $\mathbf{A}$ & $\mathbf{U}$ & D & SD & Total \\
\hline & $f(\%)$ & $f(\%)$ & $f(\%)$ & $f(\%)$ & $\begin{array}{l}f(\%) \\
(\%)\end{array}$ & $f(\%)$ \\
\hline $\begin{array}{l}\text { NCAA is adequately funded to carry out regulatory } \\
\text { oversight responsibility of the aviation industry }\end{array}$ & $\begin{array}{l}27 \\
(18.5)\end{array}$ & $\begin{array}{l}84 \\
(57.5)\end{array}$ & $\begin{array}{l}18 \\
(12.3)\end{array}$ & $\begin{array}{l}16 \\
(11)\end{array}$ & $\begin{array}{l}1 \\
(0.7)\end{array}$ & $\begin{array}{l}146 \\
(100)\end{array}$ \\
\hline $\begin{array}{l}\text { Private investors have been adequately encouraged to } \\
\text { invest in the aviation sector, through public private } \\
\text { partnership in order to develop world class infrastructure } \\
\text { and improve managerial efficiency }\end{array}$ & $\begin{array}{l}17 \\
(11.6)\end{array}$ & $\begin{array}{l}67 \\
(45.9)\end{array}$ & $\begin{array}{l}30 \\
(20.6)\end{array}$ & $\begin{array}{l}28 \\
(19.2)\end{array}$ & $\begin{array}{l}4 \\
(2.7)\end{array}$ & $\begin{array}{l}146 \\
(100)\end{array}$ \\
\hline $\begin{array}{l}\text { Technical personnel are adequately trained to ensure } \\
\text { professionalism and achieve high level of safety, security } \\
\text { and efficiency in air operations. }\end{array}$ & $\begin{array}{l}28 \\
(19.2)\end{array}$ & $\begin{array}{l}60 \\
(41.1)\end{array}$ & $\begin{array}{l}28 \\
(19.2)\end{array}$ & $\begin{array}{l}29 \\
(19.8)\end{array}$ & $\begin{array}{l}1 \\
(0.7)\end{array}$ & $\begin{array}{l}146 \\
(100)\end{array}$ \\
\hline $\begin{array}{l}\text { Government has not created a fair and conducive } \\
\text { environment for private investors in order to ensure a } \\
\text { strong and sustainable aviation industry that is competitive } \\
\text { in a global and liberalised environment. }\end{array}$ & $\begin{array}{l}32 \\
(21.9)\end{array}$ & $\begin{array}{l}49 \\
(33.6)\end{array}$ & $\begin{array}{l}37 \\
(25.3)\end{array}$ & $\begin{array}{l}22 \\
(15.1)\end{array}$ & $\begin{array}{l}6 \\
(4.1)\end{array}$ & $\begin{array}{l}146 \\
(100)\end{array}$ \\
\hline $\begin{array}{l}\text { The implementation of civil aviation policy seems to have } \\
\text { enjoyed committal of funds and the establishment of } \\
\text { structures needed to facilitate the expected policy } \\
\text { outcomes. }\end{array}$ & $\begin{array}{l}20 \\
(13.7)\end{array}$ & $\begin{array}{l}53 \\
(36.3)\end{array}$ & $\begin{array}{l}50 \\
(34.2)\end{array}$ & $\begin{array}{l}20 \\
(13.7)\end{array}$ & $\begin{array}{l}3 \\
(2.1)\end{array}$ & $\begin{array}{l}146 \\
(100)\end{array}$ \\
\hline $\begin{array}{l}\text { All necessary technology, equipment, methodology and } \\
\text { procedure are made available and accessible to civil } \\
\text { aviation departments and agencies to prevent and counter } \\
\text { new and emerging threats. }\end{array}$ & $\begin{array}{l}18 \\
(12.3)\end{array}$ & $\begin{array}{l}44 \\
(30.1)\end{array}$ & $\begin{array}{l}34 \\
(23.3)\end{array}$ & $\begin{array}{l}41 \\
(28.1)\end{array}$ & $\begin{array}{l}9 \\
(6.2)\end{array}$ & $\begin{array}{l}146 \\
(100)\end{array}$ \\
\hline $\begin{array}{l}\text { NCAA has effectively enforced compliance with ICAO } \\
\text { provision on aircraft noise and emission control }\end{array}$ & $\begin{array}{l}32 \\
(21.9)\end{array}$ & $\begin{array}{l}54 \\
(37.0)\end{array}$ & $\begin{array}{l}34 \\
(23.3)\end{array}$ & $\begin{array}{l}21 \\
(14.4)\end{array}$ & $\begin{array}{l}5 \\
(3.4)\end{array}$ & $\begin{array}{l}146 \\
(100)\end{array}$ \\
\hline $\begin{array}{l}\text { AIB has been autonomous in carrying out a thorough and } \\
\text { impartial air accident investigations and reports. }\end{array}$ & $\begin{array}{l}75 \\
(51.4)\end{array}$ & $\begin{array}{l}47 \\
(32.2)\end{array}$ & $\begin{array}{l}15 \\
(10.3)\end{array}$ & $\begin{array}{l}8 \\
(5.4)\end{array}$ & $\begin{array}{l}1 \\
(0.7)\end{array}$ & $\begin{array}{l}146 \\
(100)\end{array}$ \\
\hline $\begin{array}{l}\text { The objective of government to ensure the culture of safety } \\
\text { management is exhibited in all civil aviation activities. }\end{array}$ & $\begin{array}{l}44 \\
(30.1)\end{array}$ & $\begin{array}{l}44 \\
(30.1)\end{array}$ & $\begin{array}{l}20 \\
(13.7)\end{array}$ & $\begin{array}{l}28 \\
(19.2)\end{array}$ & $\begin{array}{l}10 \\
(6.9)\end{array}$ & $\begin{array}{l}146 \\
(100)\end{array}$ \\
\hline
\end{tabular}

Source: Field Survey, 2018

Note: $\mathrm{SA}=$ Strongly agree, $\mathrm{A}=$ Agree, $\mathrm{U}=$ Undecided, $\mathrm{D}=$ Disagree and $\mathrm{SD}=$ Strongly disagree

The results in table 3 above show that $57.5 \%$ and $18.5 \%$ of the respondents agreed and strongly agreed respectively with the statement that "NCAA is adequately funded to carry out regulatory oversight responsibility of the aviation industry". This implies that the implementation of NCAP as far as NCAA is concerned does not suffer from lack of funding.

Similarly, a large percentage of $45.9 \%$ of the respondents agreed with the statement that "Private investors have been adequately encouraged to invest in the aviation sector, through public private partnership in order to develop world class infrastructure and improve managerial efficiency". In addition, $41.1 \%$ of the respondents agreed with the statement that "Technical personnel are adequately trained to ensure professionalism and achieve high level of safety, security and efficiency in air operations". Also, 33.6\% and $21.9 \%$ of the respondents agreed and strongly disagreed with the statement that "Government has not created a fair and conducive environment for private investors in order to ensure a strong and sustainable aviation industry that is competitive in a global 
and liberalised environment". This suggests that the laws, regulations, procedures and processes put in place have not been favourable to private investors to yield the expected policy outcomes. The survey showed that a cumulative $50 \%$ of respondents agreed with the statement that "the implementation of civil aviation policy seems to have enjoyed committal of funds and the establishment of structures needed to facilitate the expected policy outcomes".

Further, $30.1 \%$ of the respondents agreed that "All necessary technology, equipment, methodology and procedure are made available and accessible to civil aviation departments and agencies to prevent and counter new and emerging threats". Also, 37.0\% of the respondents agreed with the statement that "NCAA has effectively enforced compliance with ICAO provision on aircraft noise and emission control". Half, $51.4 \%$ of the respondents strongly agreed with the statement that "AIB has been autonomous in carrying out a thorough and impartial air accident investigations and prevention". The result also showed that a cumulative $60.2 \%$ of the respondents agreed with the statement that "The objective of government to ensure the culture of safety management is exhibited in all civil aviation activities". This indicates that the implementers of civil aviation policy have embraced safety culture that agrees with the zero accident tolerance of the civil aviation policy in their activities

The descriptive statistics as presented in Table 4 below show the summary of the respondents' views on the Extent of the Implementation of National Civil Aviation Policy in line with the set goals and objectives.

Table 4: Descriptive Statistics of the Extent of the Implementation of National Civil Aviation Policy in Line with the Set Goals and Objectives

\begin{tabular}{|c|c|c|c|c|}
\hline ITEMS & Weight & Mean & SD & Rank \\
\hline $\begin{array}{l}\text { NCAA is adequately funded to carry out its regulatory oversight } \\
\text { responsibility of the aviation industry }\end{array}$ & 558 & 3.822 & 0.767 & 2 \\
\hline $\begin{array}{l}\text { Private investors have been adequately encouraged to invest in the aviation } \\
\text { sector, through public private partnership in order to develop world class } \\
\text { infrastructure and improve managerial efficiency }\end{array}$ & 503 & 3.445 & 0.897 & 8 \\
\hline $\begin{array}{l}\text { Technical personnel are adequately trained to ensure professionalism and } \\
\text { achieve high level of safety, security and efficiency in air operations. }\end{array}$ & 523 & 3.582 & 0.938 & 4 \\
\hline $\begin{array}{l}\text { Government has not created a fair and conducive environment for private } \\
\text { investors in order to ensure a strong and sustainable aviation industry that is } \\
\text { competitive in a global and liberalised environment. }\end{array}$ & 517 & 3.541 & 0.982 & 6 \\
\hline $\begin{array}{l}\text { The implementation of civil aviation policy seems to have enjoyed } \\
\text { committal of funds and the establishment of structures needed to facilitate } \\
\text { the expected policy outcomes. }\end{array}$ & 505 & 3.459 & 0.892 & 7 \\
\hline $\begin{array}{l}\text { All necessary technology, equipment, methodology and procedure are made } \\
\text { available and accessible to civil aviation departments and agencies to } \\
\text { prevent and counter new and emerging threats. }\end{array}$ & 459 & 3.144 & 1.059 & 9 \\
\hline $\begin{array}{l}\text { NCAA has effectively enforced compliance with ICAO provision on aircraft } \\
\text { noise and emission control. }\end{array}$ & 525 & 3.596 & 0.951 & 3 \\
\hline $\begin{array}{l}\text { AIB has been autonomous in carrying out a thorough and impartial air } \\
\text { accident investigations and reports. }\end{array}$ & 625 & 4.281 & 0.755 & 1 \\
\hline $\begin{array}{l}\text { The objective of government to ensure the culture of safety management is } \\
\text { inherent in all civil aviation activities. }\end{array}$ & 522 & 3.575 & 1.070 & 5 \\
\hline
\end{tabular}

Source: Field Survey, 2018

The results show that respondents agreed with all the 9 statements. This suggests that respondents have positive view about implementation of National Civil Aviation Policy in line with the set objectives. The item with statement that "AIB has been autonomous in carrying out a thorough and impartial air accident investigations and reports" was ranked first with mean value of 4.281. Also, the least ranked item was the statement that "All necessary technology, equipment, methodology and procedure are made available and accessible to civil aviation departments and agencies to prevent and counter new and emerging threats" was the least ranked item with the mean score of 3.144.

All the respondents interviewed unanimously disclosed that most of the programmes contained in NCAP had not been implemented. As a matter of fact, $40 \%$ of the provision of NCAP had not been implemented. The National Carrier project which was supposed to have been rolled out by $24^{\text {th }}$ of December 2018 as gathered has however not been implemented till date.

\section{Major Findings}

From the analysis of the data gathered, it was revealed concerning the programmes put in place by the Ministry of Aviation towards the implementation of civil aviation policy that: 
A number of programmes such as the development of aerotropolis, the plan to develop Lagos airport to become the hub of West Africa, commercialisation and privatisation of airports, the building of cargo terminals, the supply of Jet A -1 to the aviation industry by NNPC, remodelling of major airports among others were developed by the Ministry of Aviation and entrenched in the 2013 NCAP.

On the extent of implementation, it was gathered that most of the programmes identified and entrenched in the 2013 NCAP are yet to be implemented or fully implemented. Apart from remodelling of the major airport terminals, most of the provisions of the 2013 NCAP have been thrown to the winds. The National Carrier project which was expected to have rolled out and become fully operational before the end of 2018 had not seen the light of the day. The project which was going to be termed 'Flag Carrier' would be largely driven by the private sector with government owing less than $49 \%$ of the shares. The effective implementation of this project would no doubt create employment opportunities and also increase aviation sector's contribution to the country's GDP.

\section{Conclusion and Recommendations}

Based on the findings of this study, it can be concluded that various programmes were put in place by the ministry of aviation towards the implementation of government policy on civil aviation; results also showed that most of the programmes are merely existing on paper and are yet to be implemented. This study concludes that Nigeria does not lack good and laudable policies especially as far as civil aviation is concerned. The vision of the Nigeria's aviation sector is to have a safe and secure aviation industry that is pivotal to economic development but how can we have a safe and secure air transport sector when all programmes that are geared towards the realisation of that goal have been neglected and left unimplemented.

The implementation of government policy on civil aviation has suffered effective implementation which has impeded the attainment of the desired impact civil aviation is expected to have on the country's economic development.

The following recommendations are offered to ensure the effective implementation of government policy on civil aviation especially in southwestern Nigeria.

There should be laws that mandate every government that comes to power to complete all ongoing projects and programmes of their predecessors before embarking on a fresh project. There should be continuity in policy implementation especially if the policy is economically viable. Government should enforce the mandatory supply of Jet A-1 by NNPC to the aviation sector in order to reduce running cost in the industry. The laws, policies and procedures in the aviation sector should be encouraging to attract private investors to the industry.The issue of safety and security which are made explicit in the zero accident policy of the industry should be given utmost attention and its compliance should be enforced by the relevant aviation departments as development in the sector largely depends on safety. Government should organize regular workshops and seminars where implementers will be sensitized on the programmes of the National Civil Aviation Policy, the strategies to be adopted for implementing the programmes as well as the goals and objectives of the programmes such that everyone knows what is/are to be done and what they are working towards.

\section{References}

African Civil Aviation Commission. (2013) Efforts and Commitment Towards the Provision of Sustainable Aviation Training in Africa. Abuja

Ajaegbu, F.O. \& Eze, E. (2010) Public Policy Making and Analysis. Enugu: Spring Time Press.

Bhuyan, A., Jorgensen, A. \& Sharma, S. (2010). Taking the Pulse of Policy: The Policy Implementation Assessment Tool. Washington, D.C.: U.S Agency for International Development.

Dick, I. (2003) Contemporary Public Administration: The Nigerian Perspective. Enugu: John Jacob Classic Publishers

Ezeani, E.O. (2006). Fundamentals of Public Administration. Enugu: Snaap Press Ltd.

Federal Government of Nigeria. (2013) National Civil Aviation Policy

Ikelegbe, A.O. (1996). Public Policy Making and Analysis. Benin City: URI Publishing Ltd

Ikelegbe, A. (2006). Public Policy Analysis: Concepts, Issues and Cases. Lagos: Imprint Services.

Kraft, M. \& Furlong, S. (ed) (2007) Public Policy: Politics and Analysis. Washington: C.Q Press

Meter, D. \& Horn, C. (1975) "The Policy Implementation Process: A Conceptual Framework". Administration and Society, $6(4), 445-488$

Nakamura, R. \& Smallwood, F. (1981). The Politics of Policy Implementation. New York: St Martin's Press.

Nwankwo, B. \& Apeh (2008). Development Administration: Principles and Practice. Enugu: Zik Chucks Publishers.

Nweke, E. (2006). Public Policy Analysis: A Strategic Approach. Enugu: John Jacobs Publishers.

Sabatier, P \& Mazmanian, D. (1980) "The Implementation of Public Policy: A Framework of Analysis". Policy Studies Journal, 8, 538-560. 